\title{
3. Fragile Alliances
}

\author{
The Bourse du Travail Protests, Paris, 2008-2010
}

"The sans-papiers are in the front row. The sans-papiers are the first victims. The supporters and the associations must not leave us aside; this is our struggle. We are the ones who know our difficulties, our situation. The sans-papiers must understand that the struggle of the sans-papiers is their own struggle."

\begin{abstract}
In May 2008, three sans-papiers collectives occupied the Bourse de Travail in Paris, the headquarters of the CGT trade union. This was the start of one of the largest precarious migrant protests in recent French history. The sans-papiers protested against the trade union push for leadership in a movement previously self-organized by migrants. Analyzing the interactive dynamics in these protests, the chapter carves out a key aspect of such precarious mobilizations: the fragility of ties both between migrants and allies as well as within heterogeneous precarious migrant collectives.
\end{abstract}

Keywords: Paris; sans-papiers; alliances; migrant protest; trade unions

After the highly contentious St. Bernard church protests by undocumented migrants starting in 1996 and lasting roughly until 2002, the visibility of self-organized protest by migrants in Paris temporarily faded (Nicholls and Uitermark 2016). The so-called circulaire Chevènement of 1997 had formalized a "case-by-case" approach of regularization. Various sans-papiers collectives had organized protest events but they increasingly focused on direct and often secret negotiations with the respective prefect's office to obtain regularization for their members.

1 Quoted in $\operatorname{CSP}_{75}$ (2008b), author's translation.

Steinhilper, E., Migrant Protest: Interactive Dynamics in Precarious Mobilizations. Amsterdam: Amsterdam University Press 2021 DOI: 10.5117/9789463722223_CHO3 
This relatively routinized arrangement was shaken up profoundly in early 2008, when the second-largest trade union at the time, $\mathrm{CGT},{ }^{2}$ launched a coordinated strike of sans-papiers. Aiming at a regularization of sans-papiers via proofs of employment, the trade union had since 2006 organized scattered strikes to pressure employers into issuing contracts for their illegalized work force. While being welcomed by many migrant support organizations, the intervention of the CGT spurred fierce opposition by sans-papiers collectives. Three of these collectives, including the Coordination 75 des sans papiers $\left(\mathrm{CSP}_{75}\right){ }^{3}$ which claimed the legacy of the St. Bernard church protests, occupied the Bourse de Travail, the headquarter of the CGT trade union, in May 2008. It sparked one of the largest precarious migrant protests in recent French history, which lasted for two years. ${ }^{4}$

Analyzing the interactive dynamics in these protests, the chapter carves out two key aspects of precarious migrant mobilizations: the fragility of alliances and the importance of autonomy. This constellation of actors, antagonizing a leftist trade union and the autonomous sans-papiers collectives, questions the "fiction" (Jasper 2014: 14) of a homogenous migrant rights movement. Targeting an increasingly influential player within a broader movement, the migrants involved aimed at underlining that their struggle was as much a struggle for rights including regularization as it was one for autonomy and recognition as autonomous political subjects. The chapter furthermore unveils the fragile nature of alliances within protesting migrant communities. Mobilizing within small "niche openings" (Nicholls 2014) to a regular status, precarious migrants often internally compete for rights and recognition. This leads to fissures within compound players, whose unity is difficult to sustain.

\section{Protest Emergence: An Ally Turns Opponent}

Within the isolated and internally heterogeneous field of autonomous sans-papiers collectives, the $\mathrm{CSP}_{75}$ has held a central role since its official creation in 2002. Claiming the heritage of the St. Bernard collective, this umbrella organization of three collectives held something like a "monopoly"

2 Confédération générale du travail (General Confederation of Labor).

3 Coordination 75 des sans papiers is an umbrella organization of three sans-papiers collectives. The number 75 refers to the administrative department number of Paris.

4 Despite its longevity and numerical strength, the protests received comparatively little (academic) attention, not least because it unfolded parallel to the highly visible trade unionorganized strike movement (Barron et al. 2011). 
(Interview $\left.\mathrm{P}_{29}\right)^{5}$ in the self-representation of migrant claims in the public sphere, at least in Paris. Weekly rallies and occasional occupations of public buildings combined with regular meetings with the prefect's office to discuss potential regularizations had introduced a mix, almost a routine, of disruptive and nondisruptive actions into migrant activism. The usual procedure of the collectives was that they created dossiers (files) on their members, collecting proof of presence on French territory, employment and family ties, to be submitted to the prefect's office. The order of submission usually privileged those who were regularly present during demonstrations. For this purpose, the members of the collective signed a list after every protest, which both added proofs to the files and guaranteed constant presence in the public sphere. The demonstrations and particularly the occupations - more than 30 between 2002 and 2008 (Laske 2009a) - were meant to render a structurally marginalized population visible continuously and to remind the prefect's office of the mobilizing capacity of a large undocumented population in Paris (Interviews P14, P22): "We march every Friday. Because when we march, we disrupt, if we do not disrupt, no one cares about us. We are invisible but always in danger" (field notes, 16 June 2017).

When the CGT launched a coordinated strike of sans-papiers, the situation fundamentally changed. Aiming at a regularization of sans-papiers via proofs of employment, the trade union had since 2006 organized scattered strikes to pressure employers into issuing contracts for their illegalized work force - mostly in the sectors of catering services, construction and cleaning. The 2007 Hortefeux Law on immigration reform opened an additional opportunity in this regard, as it introduced the employer as a key component in the process of case-by-case admissions based on economic utility (Kahmann 2015: 421).

Acting upon this opening opportunity, from early 2008 onward, the CGT and the migrant rights association Droits devant!! strategically targeted emblematic locations to attract the broadest visibility possible (Kahmann 2015). Among them was La Grande Armée, a luxurious restaurant in the heart of Paris, which was regularly frequented by the political elites, including members of the ruling government (Le Monde Online 2008). Most of the established players in the migrant protest arena in Paris, such as GISTI, LDH and Cimade, predominantly welcomed the involvement of the CGT and particularly the new dynamic as a "turning point" in mobilizations for the rights of undocumented migrants. ${ }^{6}$ They had even created a working 
group on "trade unions and sans-papiers" (Carrère 2009) to coordinate their cooperation. During the mobilization, a new compound player referred to as Les Onze ${ }^{7}$ (The Eleven) emerged, comprising of both migrant rights associations and trade unions.

Encouraged by the substantial media coverage and positive responses received in April 2008, a coordinated strike movement was initiated by the CGT, particularly its Parisian branch, the Union departementale de Paris. Rapidly, the strike movement introduced the notion of the "sanspapier worker," framing undocumented migrants as a productive and well-integrated part of French society. This association with labor struggles also had a strategic component, as it naturally strengthened the role of trade unions in contentious migration politics around migration, ${ }^{8}$ who had previously mainly operated as logistic support for autonomous sans-papiers collectives (Kahmann 2015).

Yet, the intervention of the CGT also introduced fundamental ruptures. Firstly, the appearance of a powerful player on the scene undermined the previously central role of the autonomous collectives of sans-papiers and their struggles for both regularization and recognition as political subjects. Secondly, the CGT aimed at targeting a new constituency for their trade union and focused on migrant workers, thereby, more or less deliberately excluding those not fitting into this category. The autonomous sans-papiers collectives, in turn, had since the 1990s resisted a privileged treatment of those undocumented migrants with a higher likelihood of regularization (Interviews P22, P14). Thirdly, the CGT focused on strikes of illegalized workers at their work place. This, again, excluded the so-called "isolated workers," meaning individuals scattered across multiple companies without the bargaining power to collectively exert pressure on the employer ${ }_{\left(\mathrm{CSP}_{75}\right.}$ 2008a; Carrère 2009).

The CGT and also Droits devant!! had provided logistical and ideational support for the sans-papiers collectives, at least since the St. Bernard protests in the second half of the 1990s (Cissé 2002; Diop 1997; CSP75 2008a). Consequently, the $\mathrm{CSP}_{75}$ had at the beginning enthusiastically welcomed the initiative by the two organizations and hoped for a concerted pressure

7 The group consisted of the trade unions CGT, CFDT (Confédération française démocratique du travail, French Democratic Confederation of Labor), FSU (Fédération syndicale unitaire, Unitary Trade Union Federation), Solidaires, UNSA (Union nationale des syndicats autonomes, National Union of Autonomous Trade Unions), and the human rights associations Autre monde, Cimade, Droits devant!!, Femmes égalité, RESF (Réseau education sans frontières, Network for Education without Borders) and LDH (Veron 2011).

8 For a detailed analysis of the strike movement, see Barron et al. (2011). 
for the benefit of all sans-papiers (Barron et al. 2011; CSP75 2008a). The sans-papiers collectives, hence, joined the strike pickets of the CGT, yet, they were encouraged by the trade union to organize their own, independent strikes. However, as they routinely submitted files to the prefect's office, they were rejected on the premise that the prefect's office was busy dealing with CGT files. Encouraged by the prefect to join the activities of the CGT, the $\mathrm{CSP}_{75}$ envisaged not only the endangerment of migrant autonomy and leadership in sans-papiers mobilizations, but also feared losing their bargaining power with the state altogether (Interviews $\mathrm{P}_{22}, \mathrm{P}_{29}, \mathrm{P}_{30}$ ). The $\mathrm{CSP}_{75}$ felt deliberately sidelined and noted: "They think we are kids. We have understood that there was an agreement to block our movement. We were betrayed" (CSP75 2008a, author's translation).

Outraged, more than 200 sans-papiers deviated from their traditional weekly demonstration route on 2 May 2008, and occupied the court and staircases of the historical labor house Bourse du Travail, the headquarter of the Paris branch of the CGT, which had initiated the strike movement (Remande 2008; Le Monde Online 2008). The occupation soon involved more than a thousand sans-papiers from various origins, mostly West and North African. Among them were men, women and children with diverse migration histories united by precarious lives. Some had arrived in France as political refugees and became undocumented later, and others were rejected asylum seekers or overstayers of a tourist or student visa $\left(\mathrm{CSP}_{75}\right.$ 2008a, 2008f, 2008g). Targeting and exerting pressure on one of its long-term allies, the $\mathrm{CSP}_{75}$ demanded the CGT to either include them in their activities or leave the protest arena of undocumented migrant activism.

\section{Protest Incubation: Interactive Dynamics at the Bourse du Travail}

The protest arena initially consisted of four main compound players: the trade union CGT, the various "associations" (mostly referred to as one compound player), the $\mathrm{CSP}_{75}$, and the French executive, mainly represented by the prefect's office. Various players split in the course of the mobilizations, and others entered the arena at a later stage. During the occupation, immediately, an agitated atmosphere unfolded between the sans-papiers and the CGT, resulting in a highly antagonistic rhetoric: "The CGT has taken our movement hostage. We've taken the Bourse du Travail hostage" (sans-papiers spokesperson cited in Remande 2008, author's translation). In a public statement, the $\mathrm{CSP}_{75}$ further clarified: "Among our conditions is that, once and for all, the orchestrated infantilization of an autonomous 
movement has to stop. We are upright men and women, responsible and capable of taking our movement into our own hands. We have our dignity" (CSP75 2008a, author's translation).

For the $\mathrm{CSP}_{75}$, the involvement of the CGT in contentious migration politics was not only a question of leadership, but an assault on their proud tradition of autonomy since the St. Bernard protests. The $\mathrm{CSP}_{75}$ 's view that the CGT tried to strategically undermine the collectives' leadership was well-founded. With the strike movement, the CGT had explicitly aimed at gaining control of the sans-papiers movement, which they considered to be dominated by inefficient autonomous collectives with a focus on hunger strikes and the occupation of public spaces. The organizers of the CGT viewed particularly the hunger strikes critically as a "sordid, individual mode of action, based on an apolitical human rights discourse" (Kahmann 2015: 420). Instead, following its mandate, the CGT aimed at redirecting the movement toward a focus on labor. This also allowed for limiting the engagement to those migrants already present on French territory without engaging in highly contested claims on less restrictive immigration policies. To mark its difference compared to previous mobilizations, the CGT used the term "sans-papiers" only in combination with the qualifier "worker" ("travailleurs sans papiers"). One of the trade union organizers at the time recalled:

The question of work, immediately we perceived it as determinate. For a trade union, this question necessarily goes beyond manifestations of solidarity or support, things we have done in the past in our relationships with the sans-papiers collectives. This means that we enter into a dimension that is completely linked up with our traditions as a trade union that is to defend workers' rights. [...] From the very beginning, this was more understood as a trade union thing. (Quoted in Kahmann 2015:419)

While the CGT profited from increased visibility and public recognition, associations involved in migrant solidarity also welcomed the new momentum introduced by the trade union. According to Marcus Kahmann,

the competences that unionists brought to the table [were also] clearly recognized and valued by employers and government officials alike. They provided them with a clear advantage over other external groups (autonomous sans-papiers groups; immigrant rights and nationality groups) operating in the field. The latter lack technical and tactical competences to pursue a labor conflict and are considered as unreliable by the authorities. $(2015: 420)$ 
To justify their recognition and newly acquired privileged status in negotiating with the state, the CGT pushed for effective leadership. Unlike in preceding mobilizations, migrants were gradually excluded from the decisions and the process was steered by a small core of white and male trade union organizers (Kahmann 2015: 420; Interview P29): "Well, [in the CGT] there are many who are socialized in a political tradition - very Marxist, centralist, a bit Stalinist you could say. They really wanted to be in control of the strike movement" (Interview P29).

Kahmann highlights the socialization of the main organizer, too, who "was an ex-public transport mechanic in his 6os with a marked background in revolutionary Communism" (2015:417). Accordingly, the CGT organized the strikes their way: hierarchically, outcome oriented and with profound skepticism toward self-organized migrant collectives. Particularly, they showed little sensitivity regarding racism, emancipation and the lengthy struggles fought by sans-papiers for autonomy from nonmigrant French supporters of all kinds:

The CGT organized this movement [...] secretly. [...] Hence, it is true that the collectives at the time felt left aside. But it was also them who had a bit the monopoly in the struggles and I think an actor like the CGT, who enters the movement, could be also seen as a rival. [...] I think there is this entire discussion, that unfolded in the movement of sans-papiers - the question as to whether the struggles should be totally autonomous [from the French supporter community]. And it is true that the fact that the trade union entering the movement could be perceived positively by many, but regarding the idea of autonomy, it shakes up the idea of autonomy. $\left(\right.$ Interview P29) ${ }^{9}$

Accordingly, the CGT and the CSP 75 - two compound players with highly distinct visions of the movement regarding strategy and leadership - entered into a contentious interaction. While the CGT had an institutional interest in the leadership of the movement and an output-oriented strategy, the $\mathrm{CSP}_{75}$ viewed their mobilization as an emancipatory process to gain recognition as political subjects and at modifying the power relations vis-à-vis nonmigrant pro-beneficiaries. Additionally, the CGT's focus on collective strikes at the work places de facto meant the exclusion of large parts of the constituency of the $\mathrm{CSP}_{75}$, including all "isolated workers" without the option to pressurize collectively, as well as the women, the elderly and the sick without a job. 
When the $\mathrm{CSP}_{75}$ demanded from the CGT to recognize their role, and also include nonworking and isolated sans-papiers in their negotiations ( $\mathrm{CSP}_{75}$ 2008a, 2008b), the CGT responded: "Our job is not to file applications based on family life or medical condition, etc. We are a labor union" (cited in Barron et al. 2016). While the CGT reiterated its strategic focus on the positive category "worker," the CSP75 leadership and its members saw their "niche" toward regularization shrinking. The CGT intervention, hence, constituted a broad threat for their communities and identities, but also a direct threat to themselves and their personal interests.

In addition to the trade union and the $\mathrm{CSP}_{75}$, there was a third type of compound player involved: the myriad of "associations" engaged in migrant support with a historically ambivalent relationship to the sans-papiers collectives. Due to the success of the strike movement in terms of visibility and the first successful regularizations, most associations reacted with irritation to the occupation, noting that the $\mathrm{CSP}_{75}$ had chosen the "wrong target." Instead they recommended dissolving the nonstop picket (Barron et al. 2014; $\mathrm{CSP}_{75} 2008 \mathrm{a}$ ) in order to prevent the fragmentation of what they considered the broader "migrant rights movement." A representative of RESF stated: "They should target the Ministries of the Interior or Integration, not the CGT. Those really responsible [for the misery of undocumented migrants] are inside the government, not outside. An occupation is a hostile action. While we are dividing ourselves, the government is rubbing their hands with glee" (cited in Fouteau 2009, author's translation).

The occupants were highly disappointed by this position and increasingly perceived the associations to be "on the side of the trade union" (CSP 75 2008b; Interview P22). This experience strengthened their sense of being dominated by the white French migrant rights environment more broadly (Interviews $\mathrm{P}_{14}, \mathrm{P}_{22}$ ). Various attempts to mediate in the stalemate, involving members of the most influential associations, including GISTI, LDH, and RESF, failed due to an increasing skepticism on the part of the CSP 75 and the determination of the CGT leadership to stay in control of the strike movement. The longer the occupation lasted, the more the $\mathrm{CSP}_{75}$ became alienated from both "the associations" and the CGT (CSP75 2008c; Interviews $\mathrm{P}_{22}, \mathrm{P}_{29}$ ). Their reaction nurtured the sans-papiers collectives' general suspicion toward nonmigrant organizations and their intuition to speak on behalf of sans-papiers:

The sans-papiers are in the front row. The sans-papiers are the first victims. The supporters and the associations must not leave us aside; this is our struggle. It is we who know our difficulties, our situation. The sans-papiers 
must understand that the struggle of the sans-papiers is their struggle. (Public statement at a meeting of various collectives in the occupied Bourse du Travail: CSP75 2008b, author's translation)

Given also the long history of conflicts on questions of representation in the French migrant rights movement (Cissé 2003), the intervention of the CGT touched upon a highly sensitive point. Accordingly, the tone, at times, became extremely hostile:

We have had enough of the trade union's colonialism! [...] The sans-papiers of the $\mathrm{CSP}_{75}$ have the impression that they have been constantly exploited and got nothing in return. Nowadays in France, with the trade unions we thought of as our friends, it is just like in Africa in colonial times - it is like what our parents told us about. (CSP75 2008f, author's translation)

The longer the occupation and the stalemate lasted, the more the migrant associations felt irritated by the $\mathrm{CSP}_{75}$ 's irreconcilability (Fouteau 2009; Interviews $\mathrm{P}_{7}, \mathrm{P}_{21}, \mathrm{P}_{29}$ ). None of the numerous mediations were successful, as the occupants wanted to prove a more fundamental point, an "act of emancipation" against what they perceived an outrageous assault on their dignity. One of the activists involved at the time recalled: "The $\mathrm{CSP}_{75}$ has a very proud if not jealous tradition of their autonomy, which was also something that produced a lot of conflict. The CSP75 decides to do something. If you do not follow, they do it alone. There was not much compromise" (Interview $\mathrm{P}_{7}$ ).

Even though many associations rejected the strategy of the $\mathrm{CSP}_{75}$ and criticized what they considered an unwillingness to find "pragmatic solutions" (Interviews $\mathrm{P}_{29}, \mathrm{P}_{3}$ ), they found themselves in an extremely awkward position. While they appreciated the efforts by the CGT, they refrained from outspoken criticism against the $\mathrm{CSP}_{75}$ (Interview P21). While the CGT and the $\mathrm{CSP}_{75}$ blamed each other, the prefect's office remained almost entirely out of focus: "For the prefect's office, it was a dream. It was the self-destruction of a movement. Everyone blaming each other. It was an inferno!" (Interview $\mathrm{P}_{7}$ ).

In the following weeks and months of the occupation, a paradoxical dynamic unfolded. While the occupants were increasingly isolated from the broader migrant rights movement, the occupation and the determination of the sans-papiers protesters grew.

In summer 2008, the Bourse du Travail occupation had around 1,300 participants, including various families (Bonal 20o8; Ginésy-Galano 
2009). To sustain the occupation for months, efficient structures of selforganization were set up. Mattresses and cardboard were used in shifts, money decentrally collected and food prepared for all occupants, mostly by the women involved in the occupation (CSP 75 2008c; Ginésy-Galano 2009). As one of the $\mathrm{CSP}_{75}$ organizers at the time noted in an informal conversation, the protestors sustained the occupation "à la Africaine" ("in the African way") in the absence of external support (field notes, 16 June 2017). Through the use of this expression, he was referring to the experience of organizing subsistence and also political activism under precarious conditions with scarce resources. He also pointed at the existing internal resources of the sans-papiers, including the cultural capital of the $\mathrm{CSP}_{75}$ 's leading figures.

Firstly, some of the CSP75 organizers had been living in France for many years. One activist was even involved in the St. Bernard mobilizations in 1996 and was regularized in 2006 (after thirteen years in France) but decided to stay involved in the sans-papiers collectives, "to provide a connection" to previous mobilizations and experiences (Halissat 2016, author's translation). Others had spent several years in France as legal residents, including as political refugees, and had subsequently become undocumented through legal reforms. Accordingly, they had accumulated crucial knowledge on political activism, legal and administrative processes and social capital. These figures served as "entrepreneurs" or "brokers" for the movement, crucial for compensating or buffering the structural obstacles of political mobilization in a condition of illegality. ${ }^{10}$ The memories of disappointments were the other side of the coin in this regard, since many of those with a more extensive history of activism in France transmitted frustrations from previous interactions with various compound players in the migrant rights movement. Secondly, the occupants could rely on a strong sense of solidarity, particularly within the Sub-Saharan and North African migrant communities in Paris. These social networks had ever since buffered some of the hardships experienced by those living a life in irregularity in the French capital (France Inter 2015). The migrant workers' foyers, social housing complexes mostly located in the Parisian periphery, had for a long time become essential nodes in these social nets; as access points for newcomers, as reservoirs of information and social capital but also for the provision of basic needs such as precarious shelter and

10 See also the chapter by Freedman, who has equally pointed to the role of "brokers" with specific resources in undocumented migrant activism in France (Freedman 2008). Zepeda-Millán (2016) traces similar patterns in the United States. 
food (France Inter 2015; Laske 2009a; Halissat 2016). Due to these internal resources, individuals within these networks, and to a certain degree also the sans-papiers collectives, have been less dependent on external support. ${ }^{11}$ The embeddedness in the migrant networks and particularly the foyers were important spaces to mobilize participants and resources for the occupation of the Bourse du Travail, necessary to guarantee its continuation (CSP75 2008a, 2008b, 2008c, 2008e). Thirdly, and related to the two previous types of resources, the occupying sans-papiers originated from a wide range of countries. Yet, including the spokesperson, they were Francophone, by majority, which allowed them to communicate with the local media and supporting citizens directly. Consequently, despite a continuous and at times deepening alienation of the $\mathrm{CSP}_{75}$ with both the associations and the CGT (Fouteau 2009), the protesters succeeded in sustaining the occupation and reaching out to external players. In the so-called "débats sur matelas" ("mattress debates") - referring to practice of placing all the sleeping mattresses for the occupants in one room of the occupied building - the protesters shared experiences of a life in irregularity, discussed the strategy of the struggle, but also met potential supporters and allies. Every Wednesday a protest march was organized from the occupied building to the prefect's office, and every Friday a demonstration took place in front of the occupied Bourse du Travail (CSP75 2008b 2008; Ginésy-Galano 2009; Interview P15). With the "exits," as they called it, the protesters aimed at sustaining visibility and disruption. As the organizers noted, "If you plant a tree, you have to water it. The demonstrations are our water" (CSP75 2008d, author's translation).

\section{Interactive Dynamics at Rue Baudelique}

In June 2009, after fourteen months of occupation, during which the CGT had no functioning headquarters and accepting that no significant rapprochement was taking place between the competing compound players, the CGT ordered the eviction of the premises. When the majority of the occupants had left for one of their regular demonstrations, the security services of the CGT entered the Bourse du Travail with batons and tear gas and, according to

11 This has importantly distinguished members of the West African migrant community from the newly arriving migrants coming from other regions, who were without established networks and therefore remained entirely dependent on French supporters in the La Chapelle protests scrutinized in Chapter 4. 
the newspaper Le Monde, "brutally" evicted the sans-papiers (Van Eeckhout 2009). In a press release, the CGT Paris remarked:

The delegates [of the sans-papiers] have cultivated the idea that the occupation of the Bourse du Travail might lead to the regularization of isolated undocumented workers. Voluntarily, they have led these migrant workers into a deadlock. They could have, like others, chosen to organize in the trade unions to engage in collective struggles at the work place. (CGT Paris 2009a, author's translation)

The communiqué continued, touching upon the fundamental dilemma which had characterized the protest from the outset:

Who can understand an occupation motivated by a need for help and at the same time the refusal of any kind of proposal [to solve the stalemate]? Even more fundamentally: how is it to be understood that the $\mathrm{CSP}_{75}$ wants to damage the trade union movement and particularly the CGT while at the same time demanding its support? (CGT Paris 2009a, author's translation)

In the media, the CGT reiterated its position, justifying the eviction with a need to re-establish order, and focused on the strike movement "in the front row for the regularization of sans-papiers" (cited in Le Monde Online 2009). While the CGT had succeeded achieving the regularization of more than 2,000 sans-papiers since the initiation of strikes (CGT Paris 2009a), it was exactly its position "in the front row," and the authoritarian push for leadership, that caused the protest in the first place. An activist involved at the time as a representative of an association, who later became a CGT trade union organizer, recalled:

I think the CGT is not proud of it. But, at a certain point, it was not tenable any longer. It is not only [the CGT] in the building; there are also other trade unions. There is work to do. [...] It was a very painful moment for many. And no one really understood why no compromise could be found. (Interview P29)

The eviction left the migrant rights movement in Paris more fragmented than ever (Fouteau 2009). Hundreds of precarious migrants, including entire families, found themselves stranded on the sidewalks of the Rue du Temple in central Paris. With plastic tarps and mattresses, a makeshift camp took 
form within sight of the CGT headquarters (CSP75 2009). By being expelled from the Bourse du Travail, and hence by disrupting the public with an (improvised) protest camp, the former occupants re-emerged as a contentious issue on the agenda of the prefect's office, which had deliberately kept a low profile in the previous months. Moreover, the violent intervention had temporarily reattracted widespread media coverage (Laske 2009b; Fouteau 2009). Troubled by this new politicization, and to avoid the perpetuation of the makeshift camp in the streets of Paris, the prefect's office offered the $\mathrm{CSP}_{75}$ to treat 300 cases "benevolently" under the condition that the group dismantled the camp (Fouteau 2009; Laske 2009b).

The offer fundamentally deepened internal divisions, which had already started within the occupied Bourse du Travail (CSP75 2016; Interviews $\mathrm{P}_{7}$, P29). Given the fixed number of cases referred to by the prefect's office, immediately conflicts emerged on the selection of the 300 files out of the roughly 1,300 protesters, all exhausted by months of protest in precarious conditions and deeply afraid of missing this opportunity for regularization. One of the dissidents, criticizing the $\mathrm{CSP}_{75}$ leadership, noted:

The delegates of the $\mathrm{CSP}_{75}$ have secretly created a list of names [of individuals to receive regularization] and when the first meetings at the prefect's office started, we realized that there were names [on that list of people whom] we did not even know, who had never been present during the occupation, the demonstrations and now on the sidewalk. (Quoted in Van Eeckhout 2009, author's translation)

In addition to those who did not appear on the list, there were also those who knew they would never qualify under the official criteria of regularization on economic grounds and had therefore chosen to participate in the occupation as a last resort (CSP 75 2009, 2010). As a result, the protesting group experienced its first split into various competing players, when about a hundred protesters rejected the offer and decided to stay at the Boulevard du Temple. They rebaptized their group as the Collectif sans-papiers solidaire de Paris $^{12}$ (Van Eeckhout 2009).

Alongside some of the sans-papiers, various individual supporters looked for a way out from the impasse (Fouteau 2009; Laske 2009b). For many, a rapprochement between the sans-papiers collectives, the CGT and the migrant support associations was only possible on the condition that the former occupants cleared the sidewalks outside the Bourse du Travail. It 
was believed that the immediate spatial confrontation with the CGT needed to be overcome in order to enable the antagonists to approach each other (Fouteau 2009). Consequently, in late July 2009, those former occupants who were willing to leave the sidewalks at the Bourse du Travail and who remained loyal to the $\mathrm{CSP}_{75}$ joined supporters of different backgrounds to occupy a large empty building complex in the north of Paris (NPA 2009; Laske 2009b). The supporters included factions of the CGT who had opposed the eviction of the Bourse du Travail and demanded to "find a place for [the protesting migrants], where they can breathe, gather resources and continue to make themselves heard, and to exchange with all the others in the same situation" (CGT organizer, quoted in Van Eeckhout 2009, author's translation).

The protest arena, hence, was complemented with an additional location, which gradually led to a reordering of the main compound players involved, since some split, or left the arena, while others emerged on the scene. During the first moments of the new occupation of the former health insurance administration located on Rue Baudelique, these factional dynamics became evident. When some of the sans-papiers recognized a CGT badge on one of the supporting activists, they inquired: "Are you from the CGT? [...] Is the CGT finally willing to align with us? The militant answered: 'The CGT is not a block from the basis to Thibault [secretary general, at the time], it consists of very different people"' (cited in Laske 2009b).

Indeed, while the eviction had fragmented the occupants, it had also profoundly affected some of the trade unionists and associations, who criticized the CGT's reaction (Interviews $\mathrm{P}_{7}, \mathrm{P}_{29}$ ). On the blog "Ou va la CGT?,"13 rank and file members of the trade union who deviated from the CGT position expressed fundamental criticism of the CGT leadership and declared their solidarity with the sans-papiers collectives (Ou va la CGT? 2009b, 2009a): "There is this contempt, flavored with paternalism toward our sans-papiers comrades, who demand to organize themselves; who want to lead their struggle themselves, without putting their destiny in the hands of trade union experts, of the CGT or whomever" (Ou va la CGT? 2009a, author's translation).

The official position of the CGT, yet, remained irreconcilable. On several occasions, the trade union leadership reiterated that the eviction was without alternative and attributed the stalemate and conflict entirely to the $\mathrm{CSP}_{75}$ :

After fourteen months of unfriendly occupation to say the least, and an avalanche of fierce accusations from the $\mathrm{CSP}_{75}$, it is difficult to re-establish 
a normal relationship with those responsible until they have recognized that the occupation of the Bourse du Travail and the pressure on the trade union movement was not a good choice. They have to clarify their relationship with the CGT first. (CGT Paris 2009b, author's translation)

Directly after occupying the abandoned building in the north of Paris, the CSP75 activists baptized it the "Ministry for the Regularization of All SansPapiers," deliberately deviating from the CGT"s focus on the "sans-papiers workers" (Barron et al. 2016). The enormous spatial capacity of the new protest headquarters of sans-papiers activism initially allowed for protest incubation. The occupation rapidly numbered several thousand members. A total of sixteen collectives ( $\mathrm{CSP}_{75} 2010$ ) joined the movement, including 1,300 members of a collective of Turkish and Kurdish sans-papiers. Most of them had left Turkey for political reasons; however, they were never granted asylum and ended up undocumented (Bell and Dilber 2009). The weekly demonstrations and "mattress debates" continued in addition to a wide range of other activities, from political organizing to adult literacy programs and media workshops (Bell and Dilber 2009; Interview $\mathrm{P}_{30}$ ). During a national sans-papiers demonstration in October 2009, organized from the Rue Baudelique headquarters, more than 10,000 sans-papiers gathered (Libération Online 2009), which made it the largest demonstration by undocumented migrants in French history up to that point.

Yet, despite a high level of protest activity and positive experiences in organizing sixteen collectives made up of a total of 25 nationalities, the

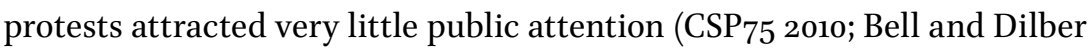
2009). The rupture with the CGT and the network of migrant rights associations had left the autonomous movement without their public voices. While proving their capacity to mobilize several thousands of precarious migrants and to organize an occupation without major internal conflicts for extended periods, they experienced a reduction in leverage vis-à-vis the state. In parallel with the occupation at Rue Baudelique, the CGT strike movement expanded further and eventually succeeded in achieving the regularization of several thousand sans-papiers (Barron et al. 2011). Both public attention and the priority of the prefect's office had shifted toward the CGT-led strike movement and the violent eviction had not lastingly damaged their reputation among influential players. Aware of this impasse and invisibility in comparison to the CGT-coordinated strikes of undocumented workers, the occupants of the building on Rue Baudelique announced a spectacular protest event in order to regain leverage: On 1 May 2010, protesters departed on a march from Paris to Nice, where the French-African Summit was to 
be held at the end of the month (Maudet 2010). In choosing a long-distance march of almost 1,00o kilometers, the protesters symbolically aligned with previous marches by sans-papiers activists such as the march in 1997 from Angoulême to Paris (Siméant 1998). Furthermore, they intended to capitalize on the relational and demonstrative effects of eventful protest. ${ }^{14}$ One of the organizers noted: "Since St. Bernard, we have needed to have a disruptive event every two or three years to maintain the visibility of our movement" (CSP75 2010: 12, author's translation).

Various migrant rights associations took the opportunity to declare their solidarity with the march and by this, also intended to send a signal of reconciliation to the CSP 75 (GISTI 2010; FTCR 2010; Médecins du Monde 2012). Despite this tentative rapprochement, the march did not result in increasing pressure on the prefect's office. Some of the participants even argued that the direction of the march was strategically wrong, as it relocated the protest arena and deviated attention and pressure from the nucleus of contention from Paris to the French periphery (Interview P15).

\section{Dynamics of Fragmentation: Niches of Regularization}

The tangible outcome of the Rue Baudelique occupation in terms of regularizations remained low, even after the eventful march. Indeed, the subsequent month unveiled the fundamental dilemma of sans-papiers activism: the prefect's office had blocked the treatment of files by sans-papiers organized in Rue Baudelique until they had left the building. While protesting against the government, the sans-papiers depended on the state's recognition. Under pressure to secure regularizations for their constituents, the $\mathrm{CSP}_{75}$ organizers signaled a willingness to make concessions. In their explanation of the envisaged end of the occupation, the $\mathrm{CSP}_{75}$ spokespersons noted:

The prefect's office told us that they did not want its [constructive] relationship with the $\mathrm{CSP}_{75}$, established over the last ten years, to suffer or come to an end as a result of the occupation. They assured us that, if the $\mathrm{CSP}_{75}$ left on its own, the relationship would be reinforced and our files would be treated in a timelier way and benevolently. If not, the relationship would end. The CSP 75 didn't want this, since it would have undermined the work of ten years. (CSP75 2010, author's translation)

14 For a more extensive analysis of the expressive and relational effects of the march, see the comparative research by Monforte and Dufour (2013). 
Similar to what Jasper termed as the "rules dilemma," the protesters found themselves trapped in rules they had aimed at changing in the first place: "Efforts to change an arena often end up following the rules of that same arena. Rather than ignoring it or using a different arena, an insurgent may end up embroiled in the arena's rules for changing the rules" (Jasper 2008: 163).

Despite spectacular protests, the $\mathrm{CSP}_{75}$ still remained with the fixed number of 300 cases offered by the prefect's office directly after the eviction from the Bourse du Travail. The $\mathrm{CSP}_{75}$ organizers were well aware that the decision regarding whom to include in the list of 300 individuals would once more introduce fissures in the movement. Nevertheless, their adherents also demanded tangible outcomes from the long and burdensome protest:

They [the prefect's office] know in advance what they will obtain: the division and weakening of the struggle. This is because, on the one hand, the sans-papiers have been waiting for many years now. It is very human [to succumb to this kind of pressure], and they are not able to resist the illusory prospect of being regularized. On the other hand, those who know they will not qualify under the "criteria" [decided by the state] are not willing to end the occupation. (CSP 75 2010, author's translation)

As expected, the question led to fierce internal divisions and fragmentation inside the occupying group about whether the conditions set by the prefect should be accepted at all, and on how to select the 300 files. These conflicts resulted in another split when more than 700 sans-papiers joined a newly established collective named Les oubliés de Baudelique ${ }^{15}\left(\mathrm{CSP}_{75} 2010\right.$; Interviews $\mathrm{P}_{15}, \mathrm{P}_{30}$ ). Many of the other collectives involved in the occupation criticized the unilateral decision of the $\mathrm{CSP}_{75}$ to end the occupation and to accept the deal offered by the prefect's office. The formerly strong and well-organized compound player, which had sustained a highly diverse occupation for months, quickly disintegrated into its constituting subplayers. Their interests became fundamentally adversarial in the light of a small niche to regularization. One of those who opposed the agreement with the authorities and joined the new collective explained: “I don't prefer the $\mathrm{CSP}_{75}$, nor the new collective. All I want is to know what happens with my case. It is important that the prefect's office knows why others like me do not want to leave the building. It is because we do not know what is going to happen with our cases" (quoted in CSP75 2010, author's translation). 
The very logic of individual case assessment, the regulatory context, permeated into the microinteractions within the contentious arena. In the context of a closing window of opportunity, the $\mathrm{CSP}_{75}$ had an interest to at least secure some success for its own adherents. Others suddenly realized their marginal role within the protests and desperately tried to find an alternative. The government authorities, well aware of the delicate unity of individuals in highly precarious conditions, from which they want to escape at all cost, strategically exploited these fragile alliances. Even though sans-papiers had for years chanted during demonstrations "le cas par cas, on n'en veut pas,"16 it was exactly this logic which fragmented the protests. Despite opposing the individual logic of regularization, the $\mathrm{CSP}_{75}$ and many other sans-papiers collectives were repeatedly forced into temporary cooperation with the state to obtain concrete results. On 7 August 2010, all the occupants left the building, bringing a two-year-long series of protests by migrants to a "painful" end (Interview P15). ${ }^{17}$

The termination of the series of protests at the Bourse du Travail and the Rue Baudelique left a deep mark on future mobilizations of precarious migrants in Paris. Interviewed seven years later, protagonists noted that it "left deep bruises" (Interview P22), and they described the effects as being "extremely painful" (Interview P15) and "profoundly damaging" (Interview P3o). Some even referred to "the dirty memory of migrant struggles" (Interview $\mathrm{P}_{7}$ ). Directly after the eviction of the Bourse du Travail, the $\mathrm{CSP}_{75}$ had even spoken of a "black moment in migrant rights mobilizations in France" (CSP75 2009). These bruises had long-lasting effects. While tensions had been inherent in the migrant rights movement and particularly in the relations between migrants and "supporters" since the 199os, the Bourse du Travail protests left the movement deeply divided: with rifts between the autonomous collectives in the St. Bernard tradition and the trade union-organized movement, between migrant support associations and sans-papiers collectives and within the sans-papiers communities. One former spokesperson of a collective involved in the Rue Baudelique occupation noted: "The Bourse du Travail episode was like the Paris Commune. There is no revolution after such moments. [...] Now, I have more contact with sans-papiers in Italy than in Paris" (Interview P15).

Disappointed by the role of the wider migrant rights movement, the $\mathrm{CSP}_{75}$ has even further cultivated the conviction that they could not rely on nonmigrant support groups: "We prefer being autonomous. We know that 
we are deficient, we make mistakes. But we prefer this to being dependent" (Interview P22). Another organizer noted: "Cooperation with the CGT? No way, they evicted us! We do not forget easily" (field notes, 30 May 2017). Aware of the counter-productivity of these conflicts, which eventually benefitted the state as their common adversary, various attempts of rapprochements were made. However, the interactionist memories sat deep, as the following account illustrates: "There was a meeting to organize the twentieth anniversary of the St. Bernard protests in summer 2016. [...] There were some, willing to move forward, but the old stories of the Bourse du Travail came up again. The stories of autonomy, of the CGT" (Interview P29).

Within the migrant community, the contentious interactions had lasting detrimental effects on unity as well. Distrust has prevailed, leaving the collectives highly fragmented. Since the end of the Rue Baudelique occupation, three different groups with the same name of $\mathrm{CSP}_{75}$ (CSP 75 2016) have come into existence in Paris. A powerful mobilization involving several thousand persons splintered into different, much smaller groups, allowing prefects to continue their strategy of divide and rule, thus cultivating competition between the different groups (Interviews $\mathrm{P}_{7}, \mathrm{P}_{29}$ ).

\section{Conclusion}

The interactive dynamics unfolding during the series of protest in Paris between 2008 and 2010 underline various aspects of relational fragility in precarious activism. Firstly, the very constellation of actors in the protests points to the fact that a "movement for the rights of migrants," neatly connecting migrant rights associations, leftist trade unions and autonomous sans-papiers collectives, reifies a questionable homogeneity. These mobilizations are best understood as contentious arenas, in which a wide range of players with highly distinct interests interacted: the hierarchic and outcome-oriented tradition of CGT with an interest in placing the trade union in the limelight; the conviction of self-organized groups to be the only ones to speak for themselves; the unease of many associations with either of the two positions; and the prefect's office, on which, eventually, all actors depended but who governed the fragile ties, predominantly from a distance. In such processes of precarious contention, players emerge, split and change sides. As this account documents, the CGT as well as several other associations, all considered to be allies of the sans-papiers collectives at least since the St. Bernard movement (Cissé 1998), lost their credibility and became temporarily perceived as key opponents. 
Secondly, the analysis suggests that migrant mobilizations are often as much a struggle for rights as one for recognition as political subjects. Even if the intervention of the CGT might have favored a path to regularization, it was detrimental to the process of emancipation of precarious migrants. The series of strikes coordinated by the CGT and Droits devant!! achieved the regularization of several thousand sans-papiers (Barron et al. 2011). Yet, de facto, the intervention of the CGT introduced trade unions as a powerful intermediary between the state and the sans-papiers communities. By those sans-papiers with a years-long background in political organizing, this was perceived as a fundamental assault and a threat to the struggle for autonomy. Asymmetric positions of power, hence, introduced a sensitive breaking point in such fragile alliances. Alliances between sans-papiers collectives and pro-beneficiaries have been historically fragile, and have been repeatedly broken due to disputes regarding whom to focus on in campaigns. Hence, the experience of the Bourse du Travail and the Rue Baudelique arena fed into a tradition of widespread distrust for the $\mathrm{CSP}_{75}$ (CSP 75 2008a).

Thirdly, as Nicholls has also convincingly argued, political activism of precarious migrants faces the structural dilemma of mobilizing within small "niche openings," rather than political opportunities (Nicholls 2014). Such bottlenecks to regularization only allow for the passage of few, at the expense of the exclusion of others (Nicholls 2013, 2014). This poses particular challenges for internal unity, as despite a shared nonstatus, precarious migrants are highly heterogeneous in terms of their potential recognition by the state. ${ }^{18}$ Consequently, parts of the protest movement split from the rest on two occasions, arguing that they had been "forgotten" and left behind. In sum, this chapter carves out the interactive dynamics in precarious mobilization, which are echoed and complemented in the three cases to follow.

\section{References}

Barron, Pierre, Anne Bory, Sébastien Chauvin, and Lucie Tourette. 2014. "Les grèves de travailleurs sans papiers (2006-2010)." In Histoire des mouvements sociaux en France, edited by Michel Pigenet and Danielle Tartakowsky, 724-732. Paris: La Découverte.

Barron, Pierre, Anne Bory, Sébastien Chauvin, Nicolas Jounin, and Lucie Tourette. 2011. On bosse ici, on reste ici! Paris: La Découverte.

18 Similar dynamics can be traced for both undocumented migrants and asylum seekers. See also Chapter 5 on the Oranienplatz protests. 
- .2016. "State Categories and Labour Protest: Migrant Workers and the Fight for Legal Status in France." Work, Employment and Society 30 (4): 631-648.

Bell, Nicholas, and Orhan Dilber. 2009. "Ein etwas anderes Ministerium." Migrazine.at, no. 2009/2. http://www.migrazine.at/artikel/ein-etwas-anderesministerium.

Bonal, Cordélia. 2008. "Les papiers d'abord, le travail ensuite." Libération Online, 30 July. Paris. http://www.liberation.fr/societe/2008/o7/30/ les-papiers-d-abord-le-travail-ensuite_19296.

Carrère, Violaine. 2009. "Derrière le sans-papiers on découvre le travailleur." Plein Droit, no. 80: 27-31.

CGT Paris. 2009a. “Communiqué de l'Union Départementale CGT de Paris. La voie était sans issue." http://www.cgt.fr/La-voie-etait-sans-issue.html.

—. 20ogb. "Communiqué de Presse." http://sd3.archive-host.com/membres/ up/1451077023/200gbis/UD752207.pdf.

Cissé, Madjiguène. 1998. “Entretien avec Madjiguène Cissé.” 12 November. https:// www.bok.net/pajol/sanspap/sptextes/madjiguene4/madjiguene4.html.

- 2002. Papiere für alle. Berlin: Assoziation A.

-. 2003. "The Sans-Papiers: A Woman Draws the First Lessons." In We Are Everywhere: The Irresistible Rise of Global Anticapitalism, edited by Notes from Nowhere, 38-45. London: Verso.

CSP75. 2008a. Le Journal de la Bourse du Travail Occupée No 1.

- 2008b. Le Journal de la Bourse du Travail Occupée No 2.

- .2008c. Le Journal de la Bourse du Travail Occupée No 3.

—. 2008d. Le Journal de la Bourse du Travail Occupée No 4.

- 2008e. Le Journal de la Bourse du Travail Occupée No 6.

—. 2008f. Le Journal de la Bourse du Travail Occupée No 7.

- .2008g. Le journal de la Bourse du Travail Occupée No 9.

—. 2009. "Le journal de la Bourse du Travail occupée no 13."

—. 2010. "Le journal de la Baudelique occupée."

—. 2016. "Communiqué de la coordination des sans papiers 75." https://csp75. wordpress.com/.

Diop, Ababacar. 1997. Dans la peau d'un sans-papiers. Paris: Seuil.

Fouteau, Carine. 2009. "Epuisement d'un lieu parisien." Vacarme 49: 78-83.

France Inter. 2015. “Anzoumane Sissoko, porte-voix des sans-papiers." https://www. franceinter.fr/emissions/d-ici-d-ailleurs/d-ici-d-ailleurs-07-aout-2015.

Freedman, Jane. 2008. “The French 'Sans Papiers' Movement: An Unfinished Struggle." In Migration and Activism in Europe since 1945, edited by Wendy Pojmann, 81-96. New York: Palgrave Macmillan US.

FTCR. 2010. "Déclaration: nous soutenons les sans papiers en marche pour la régularisation!" http://www.citoyensdesdeuxrives.eu/index.php?option=com_co 
ntent\&view=article\&id=1173:marche-des-sans-papiers-paris-nice-du-1er-au31-mai-2010\&catid=59:agenda\&Itemid $=94$.

Ginésy-Galano, Mireille. 2009. "Les sans-papiers isolés de la Bourse." Plein Droit, no. 80: 32-36.

GISTI. 2010. "Nous soutenons les sans papiers en marche pour la régularisation!" https://www.gisti.org/spip.php?article1941.

Halissat, Ismaël. 2016. "Anzoumane Sissoko, combattant des régularisations." Libération Online, 22 August. http:/www.liberation.fr/france/2016/o8/22/ anzoumane-sissoko-combattant-des-regularisations_1474069.

Jasper, James M. 2008. Getting Your Way: Strategic Dilemmas in the Real World. Chicago: University of Chicago Press.

- 2014. "Introduction. Playing the Game." In Players and Arenas, edited by Jan Willem Duyvendak and James M. Jaspers, 9-32. Amsterdam: Amsterdam Universtiy Press.

Kahmann, Marcus. 2015. "When the Strike Encounters the Sans Papiers Movement: The Discovery of a Workers' Repertoire of Actions for Irregular Migrant Protest in France." Transfer: European Review of Labour and Research 21 (4): 413-428.

Laske, Karl. 2009a. "Le régularisateur." Libération Online, 1 August. http://www. liberation.fr/societe/2009/08/o1/le-regularisateur_573816.

—. 20ogb. "Les sans-papiers retrouvent un QG." Libération Online, 18 July. http:// www.liberation.fr/societe/2009/07/18/les-sans-papiers-retrouvent-un-qg_571144.

Le Monde Online. 2008. "Des cuisiniers sans papiers en grève dans un restaurant chic de Paris.” Le Monde Online, 13 February. http://www.lemonde.fr/societe/ article/2008/02/13/des-cuisiniers-sans-papiers-en-greve-dans-un-restaurantchic-de-paris_1011020_3224.html.

—. 2009. "Comment la CGT a délogé des sans-papiers." Le Monde Online, 25 June. http://www.lemonde.fr/societe/article/2009/06/25/installation-de-sans-papiersdevant-la-bourse-du-travail-a-paris_1211071_3224.html.

Libération Online. 2009. "A Paris, un défilé pour les sans-papiers." Libération Online, 10 October. http://www.liberation.fr/societe/2009/10/10/a-paris-un-defile-pourles-sans-papiers_587023.

Maudet, Elsa. 2010. "Le Paris-Nice de 80 sans-papiers." La Croix, 29 April. https:// www.la-croix.com/Actualite/France/Le-Paris-Nice-de-8o-sans-papiers-_NG_2010-04-29-603077.

Médecins du Monde. 2012. "Marche de travailleurs sans papiers de Paris à Nice." 20 February. http://www.medecinsdumonde.org/fr/actualites/presse/2012/o2/20/ marche-de-travailleurs-sans-papiers-de-paris-nice.

Monforte, Pierre, and Pascale Dufour. 2013. "Comparing the Protests of Undocumented Migrants beyond Contexts: Collective Actions as Acts of Emancipation.” European Political Science Review 5 (1): 83-104. 
Nicholls, Walter. 2013. "Fragmenting Citizenship: Dynamics of Cooperation and Conflict in France's Immigrant Rights Movement." Ethnic and Racial Studies 36 (4): 611-631.

- 2014. "From Political Opportunities to Niche-Openings: The Dilemmas of Mobilizing for Immigrant Rights in Inhospitable Environments." Theory and Society 43 (1): 23-39.

Nicholls, Walter J., and Justus Uitermark. 2016. Cities and Social Movements: Immigrant Rights Activism in the United States, France, and the Netherlands, 1970-2015. New York: John Wiley \& Sons.

NPA. 2009. "Ministère de la régularisation de tous les sans-papiers." https://npa2oog. org/content $/ \% \mathrm{C}_{2} \% \mathrm{AB} \% \mathrm{C}_{2} \%$ Aominist $\% \mathrm{C}_{3} \% \mathrm{~A} 8$ re-de-la-r\% $\% \mathrm{C}_{3} \%$ Aggularisationde-tous-les-sans-papiers $\% \mathrm{C}_{2} \% \mathrm{Ao}_{0} \mathrm{C}_{2} \% \mathrm{BB} \% \mathrm{C}_{2} \% \mathrm{Ao}$.

Ou va la CGT? n.d. "La CGT et le soutien aux sans-papiers." http://ouvalacgt.overblog.com/pages/La_CGT_et_le_soutien_aux_sanspapiers-502745.html.

—. 2009a. "Bourse du Travail: ceux qui ont approuvé l'évacuation." http://ouvalacgt. over-blog.com/article-33990549.html.

- . 2009b. "Le SO de la CGT évacue par la force les sans-papiers de la Bourse du Travail." http://ouvalacgt.over-blog.com/article-33090625.html.

Remande, Raphaëlle. 20o8. "Sans-papiers: 'La CGT a pris le mouvement en otage." Libération Online, 2 May. https://www.liberation.fr/societe/2008/05/02/ sans-papiers-la-cgt-a-pris-le-mouvement-en-otage_16370.

Siméant, Johanna. 1998. La cause des sans-papiers. Paris: Les Presses de Sciences Po.

SUD Éducation. 2010. "Le ministère de la régularisation de tous les sans-papiers lève le camp." http://sudeducation.org/Le-ministere-de-la-regularisation.html.

Van Eeckhout, Laetitia. 2009. "Les sans-papiers expulsés de la Bourse du Travail en quête d'un point de chute stable." Le Monde Online, 31 July. http://www.lemonde. $\mathrm{fr} /$ societe/article/2009/07/31/les-sans-papiers-expulses-de-la-bourse-du-travailen-quete-d-un-point-de-chute-stable_1224638_3224.html.

Veron, Daniel. 2011. "Sans-Papiers: d'un quotidien tactique à l'action collective." Variations, no. 13/14: 1-12.

Zepeda-Millán, Chris. 2016. "Weapons of the (Not So) Weak: Immigrant Mass Mobilization in the US South." Critical Sociology 42 (2): 269-287. 
